\title{
Phytochemical Screening, GC-MS Analysis, Toxicity and Antimicrobial Properties of Extracts Outer Shell Poikilospermum suaveolens (Blume) Merr
}

\author{
Abdul Hapid ${ }^{1,2 *}$, Mery Napitupulu ${ }^{3}$, and Muhammad Sulaiman Zubair ${ }^{4}$ \\ ${ }^{1}$ Faculty of Forestry, Tadulako University, Jl. Soekarno Hatta Km 9, Bumi Tadulako, Tondo, Palu 94118, Central Sulawesi, \\ Indonesia \\ ${ }^{2}$ Doctor of Agricultural Science Study Program, Postgraduate Program, Tadulako University. Jl. Soekarno Hatta Km 9, Bumi \\ Tadulako, Tondo, Palu 94118, Central Sulawesi, Indonesia \\ ${ }^{3}$ Science Department, Faculty of Teacher Training and Education, Tadulako University. Jl. Soekarno Hatta Km 9, Bumi \\ Tadulako, Tondo, Palu 94118, Central Sulawesi, Indonesia \\ ${ }^{4}$ Pharmacy Department Faculty of Math and Science, Tadulako University, Palu 94148, Indonesia \\ * Correspondence author
}

\begin{abstract}
Poikilospermum suaveolensis a medicinal plant used by local communities, especially the Kaili tribe around Lore Lindu National Park, Sigi Regency, Central Sulawesi Province, Indonesia for the treatment of breast cancer and jaundice. Because of the importance of this plant, this study was designed to determine the content of secondary metabolic compounds, toxicity, antimicrobial properties and identify the compounds through Gas chromatography mass spectrometry (GC-MS) analysis. The results of the study found that the outer skin extract of $P$. suaveolens contained alkaloids, tannins, saponins and steroids. The extract showed high toxicity with an LC50 value of $44.41 \pm 25.71 \mathrm{~m} / \mathrm{mL}$. Antimicrobial activity test showed that the extract with a concentration of $25 \%$ had the inhibition of bacterial growthStaphylococcus aureus $16.17 \pm 0.29 \mathrm{~mm}$ (strong), Escherichia coli bacteria $14.50 \pm 0.50 \mathrm{~mm}$ (strong) and Candida albicans at $17.00 \pm 1.00 \mathrm{~mm}$ (strong). AGas chromatography mass spectrometry (GC-MS) analysis found that there were about 50 compounds in the outer shell extract of $P$. suaveolens including Lupan-3-Yl Acetate, 1,3,4,5-TetrahydroxyCyclohexanecarboxylic Acid, Dl-Threitol, 6-Octadecenoic Acid, (Z)-, L-(+)-Ascorbic Acid 2,6-Dihexadecanoate, 5-Hydroxy-7Methoxy-2-Pentylchromone, Vitamin E, 3-Methoxy-5Methylphenol, 4,6-Dioxatricyclo[ 3.3.1.02,7]Nonane, 1,3,3Trimethyl-, (1s)-, Ammoniumchlorid, Tetraoctyl-. This study found that this extract has the potential to be used as an antimicrobial source from safe natural ingredients.
\end{abstract}

Keywords:, Poikilospermum suaveolens, Phytochemicals, Toxicity, Antimicrobials, GC-MS

\section{INTRODUCTION}

$\mathrm{T}$ he world is facing a very crucial problem with the presence of Covid-19 which has spread throughout the world including Indonesia (Huo et al., 2021). The dilemma of various countries in tackling COVID-19 has made the government and even the public feel anxiety and losses that have an impact on the economy and health(Gulseven et al., 2020). One of the impacts felt by the community in the health sector is that many health facilities limit operating hours so that public health services are not optimal. Even most of the people who are sick do not dare to go to hospitals or other health facilities for fear of being exposed to Covid-19(Horesh \& Brown, 2020). This makes the community, especially local communities around the forest, prefer to use medicinal plants available in their area to treat various kinds of diseases (Supiandi et al., 2019). The use of medicinal plants for traditional medicine by communities around the forest is a local wisdom that has high value and has been passed down from generation to generation, even the world health organization reports that almost $80 \%$ of the world's population, especially traditional communities, depend on medicinal plants for their daily health care.(Hu et al., 2020; Yeshiwas et al., 2019).

Microbial infection is one type of disease that affects many people in the world and even accounts for almost $85 \%$ of global deaths due to infectious diseases such as diarrheal diseases, acute respiratory infections, measles, AIDS, tuberculosis and diarrhea. (Balali et al., 2020). Some antimicrobial agents are used specifically to treat infections and these are referred to as therapeutic agents(Tong et al., 2015). Antimicrobial compounds are compounds that can inhibit growth or even kill microbes. However, the use of these drugs available in the general market over the past few years has created a new problem, namely the occurrence of antibacterial drug resistance and triggering changes in the body of bacteria to survive in an antibiotic environment.(Chokshi et al., 2019). To overcome these problems, the community and researchers are looking for several new alternatives that can be used as antimicrobial materials, which are safe, cheap and easily available in nature.

Poikilospermum suaveolens (Blume) Merr is Poikilospermum suaveolens (Blume) Merr. In the Kaili Tribe, especially those living around the forest, the extract of the outer skin is used as a medicine for breast cancer and jaundice. Currently, there are no detailed studies on the secondary metabolic content, compound content, toxicity and antimicrobials of the outer 
bark extract of the medicinal plant P. suaveolens. Therefore, this study was designed to determine the content of secondary metabolic compounds, their toxicity, antimicrobial properties and identify the active compounds through gas chromatography mass spectrometry (GC-MS) analysis.

\section{MATERIALS AND METHODS}

\section{Plant material collection and preparation of plant extracts}

Samples of medicinal plants were obtained from the Lore Lindu National Park area, Sigi Regency, Central Sulawesi Province, Indonesia with the assistance of the Kalili Tribe Community in January-February 2020. The sample was identified as Poikilispermum suaveolens (Blume) Merr (Urticiceae Tribe) by the Biological Research Center of the Institute of Sciences Indonesia (LIPI) Cibinon, Indonesia. The stem samples of P. suaveolens were collected from the forest and then washed with running water then took the outer bark and dried in a place protected from direct sunlight for 10 days. The dry sample was ground with a hammer mill. The sample simplicia was soaked in $96 \%$ ethanol for 3 days and then filtered with Whatman 42 filter paper to produce filtrate and residue. Immersion was carried out 3 times until the filtrate was close to clear.

\section{Screening of Phytochemicals}

Phytochemical screening carried out included tests for alkaloids, triterpenoids and steroids, saponins, phenols, flavonoids and tannins. The analytical method used is based on(Harborne, 1987)

\section{GC-MS Analysis}

The ethanol extract of the sample was analyzed for its chemical components using the GC-MS Agillent 7890A series instrument. The analysis used an HP-5MS capillary column with a helium carrier, with a maximum temperature of $350 \mathrm{C}$ for 20 minutes, an injection temperature of $250 \mathrm{C}$, a detector temperature of $250 \mathrm{C}$ and a column initial temperature of 100 $\mathrm{C}$ with an increase of $15 \mathrm{C}$ per minute to $350 \mathrm{C}$ and an ionization energy of $70 \mathrm{eV}$. Identification of compounds is done by matching the sample spectrum data with the compound spectrum contained in the library.

\section{Toxicity Test}

Toxicity testing uses the brine shrimp lethality test (BSLT) method which refers to (Meyer et al., 1982). Before determining the toxicity test, a preliminary test is carried out. The concentration of the sample extract used was $1000 \mathrm{ppm}$, $500 \mathrm{ppm}, 250 \mathrm{ppm}, 100 \mathrm{ppm}, 50 \mathrm{ppm}$ and $0 \mathrm{ppm}$ (control). The stock solution was prepared by dissolving $100 \mathrm{mg}$ of the sample in $0.5 \mathrm{ml}$ of ethanol and $49.5 \mathrm{ml}$ of seawater. A total of 10 Artemia salina nauplius in $4 \mathrm{ml}$ of seawater were put into a vial containing $1 \mathrm{ml}$ of sample extract solution. At each concentration, 3 repetitions were carried out. All vials were incubated at room temperature for 24 hours under 20 watt TL lamp. Observations were made after 24 hours by looking at the number of dead A. salina nauplius at each concentration(Rampe \& Tombuku, 2016).

\section{Anti Microbial Test}

Test anti Microorganisms were carried out using the inhibitory test using the well-boiling method (Carson \& Riley, 1995). The microbes used were gram-positive Staphylococcus aureus, gram-negative Escherichia coli and the fungus Candida albicans. The concentration of extract used was $25 \%$, $50 \%, 75 \%, 100 \%$, positive control Chloramphenicol 2\% (antibacterial test) and Nystatin 1\% (antifungal test). DMSO $10 \%$ negative control.Taking $25 \mathrm{~mL}$ of NA containing the test microbes from the final growth phase as much as 106 $\mathrm{CFU} / \mathrm{mL}$ was poured into a petri dish and allowed to solidify and then made a well with a diameter of $6 \mathrm{~mm}$. The well was filled with 501 of sample extract for each treatment and positive control and negative control. Then incubated at $37^{\circ} \mathrm{C}$ for 24 hours. Observation of the inhibition zone on the growth of bacteria and fungi in petri dishes was carried out by measuring the diameter of the clear zone formed using a caliper.

\section{Statistical Analysis}

Statistical analysis using the "One-way ANOVA" Analysis of Variance (ANOVA) method, if significantly different, further Ducan test was carried out. All treatments were repeated three times and data were expressed as mean \pm standard deviation (SD). Statistical calculations were performed on the original excel software.

\section{RESULTS AND DISCUSSIONS}

\section{Phytochemical screening}

The results of phytochemical screening showed that the extract was positive for containing alkaloids, tannins, saponins and steroids but was not detected to contain flavonoids (Table 1).

Table 1. Phytochemical Analysis of P. suaveolens Outer Bark Extract

\begin{tabular}{|c|c|c|}
\hline Compounds & Test results & Information \\
\hline Alkaloids & +++ & Formation of an orange precipitate \\
\hline Flavonoids & - & No color change \\
\hline Tannins & + & $\begin{array}{c}\text { The appearance of a brownish green or } \\
\text { blue black color }\end{array}$ \\
\hline Saponins & + & Formation of foam or froth \\
\hline Steroids & + & $\begin{array}{c}\text { The top layer is red and the bottom layer is } \\
\text { yellow and green }\end{array}$ \\
\hline
\end{tabular}

Information: $+++=$ Many compounds detected, $++=$ Medium compounds detected, $+=$ Fewer compounds detected, - Undetectable compound

\section{Toxicity Test}

Toxicity test using the brine shrimp lethality test (BSLT) method on Artemia salina shrimp larvae was carried out to see the mortality rate of larvae caused by sample extracts. (Meyer et al., 1982). Toxicity test using the BSLT method is an acute toxicity test where the toxic effect of a compound can be determined in a short time, easy to do, cheap, quite accurate, 
only requires a little test material, and the results have a relationship with anti-cancer activity and a $95 \%$ confidence level.(Dewi et al., 2016). The results of the toxicity test and the effect of the concentration of the outer shell extract of $\mathrm{P}$. suaveolens on the mortality of A. salina shrimp larvae are presented in table 2 below:

Table 2. Tilapia LC50 Outer Shell Extract of P. suaveolens and Effect of Concentration on Mortality of A. salina and LC50 larvae

\begin{tabular}{|c|c|c|c|}
\hline Sample & $\begin{array}{c}\text { Concentratio } \\
\mathrm{n}(\mathrm{ppm})\end{array}$ & $\begin{array}{l}\text { Larval mortality } \pm \\
\text { SD }(\mathrm{Sig}=0.000)\end{array}$ & $\begin{array}{c}\mathrm{LC} 50(\mu \mathrm{m} / \mathrm{mL}) \\
\pm \mathrm{SD}\end{array}$ \\
\hline \multirow{5}{*}{$\begin{array}{l}\text { outer shell of } \\
\text { P. suaveolens }\end{array}$} & 50 & $4.67 \pm 0.58 \mathrm{~b}$ & \multirow{5}{*}{$\begin{array}{l}44.41 \pm 25.71 \\
\quad \text { (Toxic) }\end{array}$} \\
\hline & 100 & $6.33 \pm 0.58 c$ & \\
\hline & 250 & $7.00 \pm 0.00 \mathrm{~cd}$ & \\
\hline & 500 & $7.33 \pm 0.58 \mathrm{~d}$ & \\
\hline & 1000 & $7.67 \pm 0.58 \mathrm{~d}$ & \\
\hline Control & Sea water & $0.00 \pm 0.00 \mathrm{a}$ & \\
\hline
\end{tabular}

The average value followed by different letters shows a significant difference at the level of $=5 \%$

The results of statistical analysis showed that the treatment (concentration) of the outer shell extract of P. suaveolens had a significant effect on the mortality of A. salina shrimp larvae (Sig 0.000). Further test results showed that the control (seawater) was significantly different from all treatments with the concentration of the outer shell extract of P. suaveolens on the mortality of A. salina shrimp larvae. The $50 \mathrm{ppm}$ concentration treatment was also significantly different from all other treatments, but the treatments with concentrations of $250 \mathrm{ppm}, 500 \mathrm{ppm}$ and 1,000 ppm were not significantly different in the mortality of A. salina larvae. The higher the concentration of woody lianas, the more shrimp larvae died. Increasing the concentration of P. suaveolens extract had a significant effect on the mortality of A. salina larvae up to a concentration of $250 \mathrm{ppm}$, but the increase in concentration above $250 \mathrm{ppm}$ to 1 .

The results of the toxicity calculation (Table 2) show that the outer shell extract of P. suaveolens has an LC50 of $44.41 \mathrm{ppm}$ (can kill A. salina larvae as much as $50 \%$ at a concentration of $44.21 \mathrm{ppm}$ ). By categoryMeyer et al. (1982)outer shell extract of P. suaveolens is classified as toxic (LC50 between 31-200 $\mathrm{ppm})$. This extract is toxic, presumably because of its secondary metabolic content. The results of the phytochemical analysis (table 1) showed that the outer skin extract of P. suaveolens was positive for alkaloids, tannins, saponins and steroids. The same thing was obtained byPanggabean et al. (2020) in the Ethanol Extract of the plant Zanthoxylum acanthopodium where the peel extract is toxic from other parts such as the roots, leaves and fruit because of the positive content of many alkaloid compounds. Baud et al. (2014)also said that secondary metabolites such as alkaloids are active components that act on nerves and can cause digestive disorders in A. salina larvae besides that alkaloids can act as poisons through the larvae's mouth. Alkaloids also cause the larvae to fail to get a taste stimulus so they are unable to recognize the food so that the larvae starve to death(Kacprzak, 2016). The results of other studies also found that the content of secondary metabolites of saponins and tannins can kill shrimp larvae. which are considered cancer cells because the active components in saponins and tannins can activate the mechanism of the apoptotic pathway of cancer cells, besides that saponins can also inhibit the proliferation of cancer cells.(Iswantini et al., 2011).

\section{Antimicrobial Properties}

Antimicrobial test of P. suaveolens outer shell extract using the well method at various concentrations is presented in Table 3 .

Table 3. Antimicrobial activity of outer bark extract of P. suaveolens

\begin{tabular}{|c|c|c|c|c|}
\hline \multirow{2}{*}{ Sample Type } & \multirow{2}{*}{$\begin{array}{c}\text { Concentratio } \\
n\end{array}$} & \multicolumn{3}{|c|}{ Inhibition Zone $(\mathrm{mm}) \pm \mathrm{SD}$} \\
\hline & & S. aureus & E. coli & C. albicans \\
\hline \multirow{4}{*}{$\begin{array}{c}\text { Outer Bark P. } \\
\text { suaveolens }\end{array}$} & $25 \%$ & $\begin{array}{c}16.17 \pm 0.29 \\
b\end{array}$ & $\begin{array}{c}14.50 \pm 0.50 \\
b\end{array}$ & $17.00 \pm 1.00 \mathrm{~b}$ \\
\hline & $50 \%$ & $\begin{array}{c}16.33 \pm 0.76 \\
b\end{array}$ & $\begin{array}{c}17.00 \pm 0.50 \\
\mathrm{c}\end{array}$ & $\begin{array}{c}17.67 \pm 0.58 b \\
c\end{array}$ \\
\hline & $75 \%$ & $\begin{array}{c}16.33 \pm 1.26 \\
b\end{array}$ & $\begin{array}{c}18.50 \pm 0.87 \\
\mathrm{~d}\end{array}$ & $18.83 \pm 0.29 \mathrm{c}$ \\
\hline & $100 \%$ & $\begin{array}{c}18.17 \pm 1.26 \\
\mathrm{c}\end{array}$ & $\begin{array}{c}20.33 \pm 0.29 \\
\mathrm{e}\end{array}$ & $20.33 \pm 0.58 \mathrm{~d}$ \\
\hline DMSO (K-) & $10 \%$ & $0.00 \pm 0.00 \mathrm{a}$ & $0.00 \pm 0.00 \mathrm{a}$ & $0.00 \pm 0.00 \mathrm{a}$ \\
\hline $\begin{array}{c}\text { Chloramphenic } \\
\text { ol (Control +) }\end{array}$ & $2 \%$ & $\begin{array}{c}23.67 \pm 0.76 \\
\mathrm{f} \\
\end{array}$ & $\begin{array}{c}24.33 \pm 0.29 \\
\mathrm{f} \\
\end{array}$ & 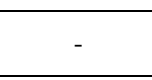 \\
\hline Nystatin $(\mathrm{K}+)$ & $1 \%$ & - & - & $29.00 \pm 1.00 \mathrm{f}$ \\
\hline Sig & & 0.000 & 0.000 & 0.000 \\
\hline
\end{tabular}

The average value followed by different letters shows a significant difference at the level of $=5 \%$

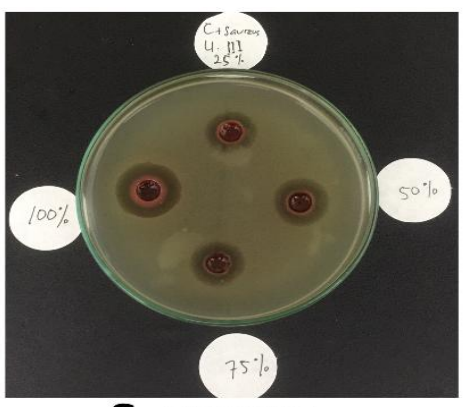

S. aureus

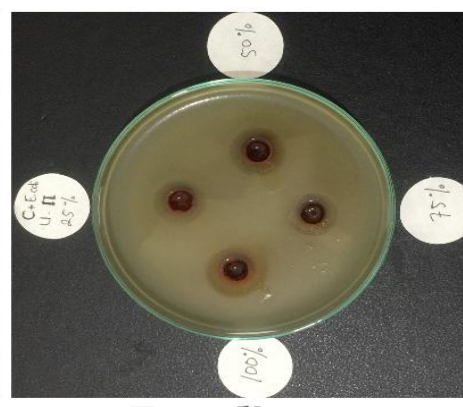

E. coli

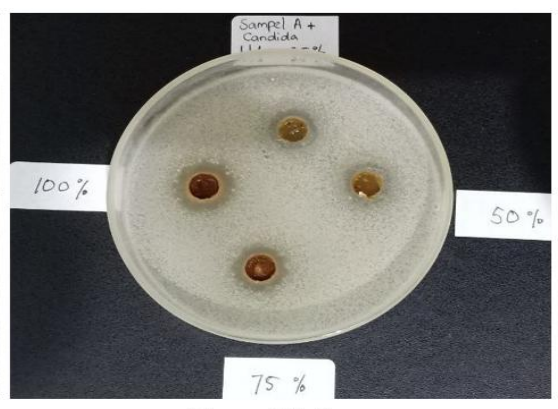

C. albicans

Figure 1. Inhibition of P. suaveolens outer shell extract on microbial growth 
The results of testing the effectiveness of the inhibition of $\mathrm{P}$. suaveolens outer shell extract against the growth of S. aureus, E coli and C. albicans fungi can inhibit which is indicated by the presence of a clear zone around the wells/holes made for each treatment (figure 1). The clear zone or zone of inhibition was not found in the DMSO solution treatment or negative control, this indicates that the solvent used did not inhibit the growth of bacteria and fungi. The ability of extract activity in forming inhibitory zones against bacterial and fungal growth can be grouped into 3 categories, namely weak inhibition having a clear zone area of $5 \mathrm{~mm}$, moderate inhibition forming a clear zone of $6-10 \mathrm{~mm}$, strong inhibition zone forming a clear zone of $11-\mathrm{mm}$. $20 \mathrm{~mm}$ and very strong inhibition to form a clear zone $20 \mathrm{~mm}$ (Davis \& Stout, 1971; Muharni et al., 2017). Based on these categories, the outer skin extract of P. suaveolens all concentrations (inhibitory capacity $16.17 \mathrm{~mm}-18.17 \mathrm{~mm}$ ) were categorized as strong inhibitors of the growth of S. aureus bacteria.

The results of statistical analysis using analysis of variance showed that the concentration of the outer shell extract of P. suaveolens had a significant effect on the effectiveness of the inhibition of the growth of $\mathrm{S}$ aureus bacteria ( $\mathrm{Sig}<0.005$ ). To determine the difference in the effect of each treatment concentration, Duncan's further test was carried out at the 5\% level. Further test results showed that the negative control (DMSO) was significantly different from all treatments, the extract at concentrations of $25 \%, 50 \%$ and $75 \%$ did not significantly differ in the effectiveness of the growth inhibition of S. aureus bacteria, after the concentration was increased to $100 \%$ the effectiveness of growth inhibition. the bacteria gave a significantly different effect at the 5\% level. The strong inhibitory power of the outer shell extract of $\mathrm{P}$. suaveolens against $\mathrm{S}$. aureus bacteria was due to the active compounds contained in the plant. The results of phytochemical analysis showed that the extract detected contained alkaloids, tannins, saponins and steroids. This is in accordance with the results of the studyFitriani (2014) who discovered alkaloid compounds in root extracts Ageratum conyzoidescan inhibit the growth of $\mathrm{S}$. aureus bacteria. Phenolic compounds detected in P. suaveolens extract were tannins. Tannin compounds have antibacterial properties because they can inhibit bacteria, the mechanism of antibacterial action of tannins is by forming complex compounds in cell proteins so that there is damage to the bacterial cell membrane and intracellular release of S.(Ibraheem et al., 2018; Jahani et al., 2016; Wolde et al., 2018).

The inhibition of the outer shell extract of P. suaveolens on the growth of E. coli bacteria was categorized into strong inhibition for extracts with a concentration of $25 \%, 50 \%, 75 \%$ and very strong for extracts with a concentration of $100 \%$. The inhibitory ability of $2 \%$ chloramphenicol positive control was also included in the category of very strong inhibitory power because it formed the inhibition zone area with an average of $24.33 \mathrm{~mm}$. The results of statistical analysis using analysis of variance showed that the concentration of the outer shell extract of P. suaveolens had a significant effect on the effectiveness of the growth inhibition of E. coli bacteria (Sig $<0.005$ ). So that the Duncan further test was carried out at the $5 \%$ level to determine the difference in the effect of each concentration. Further test results showed that all concentrations were significantly different in their effectiveness in inhibiting the growth of E. coli bacteria. The high inhibitory power of E. coli bacteria in the outer shell extract of P. suaveolens was caused by the content of secondary metabolic compounds or active compounds contained in the extract. The results of phytochemical analysis showed that the outer shell extract of P. suaveolens was detected to contain alkaloids, saponins and steroids. This is in accordance with the results of the studyDesai et al. (2009) and Sparg et al. (2004) which explains that saponins are able to inhibit the growth of gram-positive, gram-negative bacteria or as antifungals.

Based on the zone of inhibition category described by (Davis and Stout, 1971b; Satrianugraha et al., 2019) the outer shell extract of P. suaveolens with concentrations of $25 \%, 50 \%$ and $75 \%$ was included in the strong category in inhibiting the growth of the fungus $\mathrm{C}$. albicans (inhibitory power). $16.17 \mathrm{~mm}$ - $18.17 \mathrm{~mm}$ ). Extract with a concentration of $100 \%$ has an inhibition zone of $20.33 \mathrm{~mm}$ including very strong. However, it is still smaller than the positive control (nystatin) which has an inhibitory power of $29.00 \mathrm{~mm}$.

The zone of inhibition of growth of the fungus C. albicans outer shell extract of P. suaveolens was categorized as strong and very strong. This is due to the secondary metabolic content or active compounds found in plants. The results of phytochemical analysis showed that the extract was detected to contain many alkaloids, tannins, saponins and steroids. Each of these secondary metabolites has a different way of working in inhibiting growthfungus C. albicans (Alfiah et al., 2015). This is in accordance with the results of research that found alkaloid compounds in root extractsAgeratum conyzoides can inhibit the growth of the fungus $\mathrm{C}$. albicans. Saponins are also secondary metabolic compounds found in the outer shell extract of P. suaveolens. These compounds can damage cell membranes and cause various important components to come out of fungal cells, namely nucleic acids, proteins and nucleotides.(De Ornay et al., 2017; Kandoli, 2016). Steroid compounds can inhibit the development of fungi, either through the cytoplasm or interfere with the development and growth of fungal spores(Subhisha \& Subramoniam, 2005). Azizi-Lalabadi, (2019)stated that steroids can function as antifungals because the lipophilic properties possessed by steroids can inhibit spore germination in fungi. The active compounds of tannins also have antifungal properties. The antifungal mechanism possessed by tannins is their ability to inhibit the synthesis of chitin which is used for the formation of cell walls in fungi and damage cell membranes so that fungal growth is inhibited.(Preedy, 2010). 
The results of analysis of variance on the effect of extract concentration on the effectiveness of the growth inhibition of the fungus $\mathrm{C}$. albicans had a significant effect because the sig value was smaller than 0.05 or $f$ table was greater than $f$ count. To determine the difference in the effect of each treatment concentration, Duncan's further test was carried out at the 5\% level. Further test results showed that the outer bark extract of $25 \%$ concentration was significantly different with concentrations of 50\%, 75\%, $100 \%$ and positive control. But the $50 \%$ concentration was not significantly different from the $75 \%$ concentration.

In general, the effect of extract concentration was positively correlated with the effectiveness of the inhibition of the growth of bacteria and fungi. The higher the concentration of the extract, the greater the effectiveness of the inhibition of the growth of S. aureus, E coli and C. albicans fungi. This is because the higher the concentration of the extract, the higher the content of secondary metabolites that function to inhibit bacteria(Egra et al., 2019). This is also in accordance with the research of several researchers who stated that the higher the concentration of the extract, the higher the content of active substances in it so that the anti-bacterial and fungal activity will be even greater. On the other hand, the lower the concentration of the extract, the less the active substance in it, so that the antifungal activity will decrease(Fatmasari et al., 2020; Herdayanti, 2020; Kandoli, 2016; Setiari et al., 2019).

\section{GC-MS Analisis analysis}

The results of the identification of the active compound components of the outer shell extract of P. suaveolens through GC-MS analysis are presented in table 2 below:

Table 2. Compounds from GC-MS analysis of outer shell extract $P$. suaveolens

\begin{tabular}{|c|c|c|}
\hline No & Compound & $\begin{array}{c}\text { Rate } \\
(\%)\end{array}$ \\
\hline 1 & Forget-3-Yl Acetate & 12.77 \\
\hline 2 & Dl-Threitol & 8.25 \\
\hline 3 & 6-Octadecenoic Acid, (Z)- & 7.88 \\
\hline 4 & L-(+)-Ascorbic Acid 2,6-Dihexadecanoate & 6.16 \\
\hline 5 & Vitamin E & 5.5 \\
\hline 6 & 3-Methoxy-5-Methylphenol & 5.49 \\
\hline 7 & Trimethyl-, (1s)- & 5.21 \\
\hline 8 & Ammoniumchloride, Tetraoctyl- & 4.74 \\
\hline 9 & Lupeol & 4.11 \\
\hline 10 & Oleoyl Chloride & 4.08 \\
\hline 11 & 10,12-Hexadecadien-1-Ol & 2.71 \\
\hline 12 & 4,4,5,8-Tetramethylchroman-2-Ol & 2.56 \\
\hline 13 & 9-Octadecenoic Acid, Methyl Ester & 2.28 \\
\hline 14 & Selina-6-En-4-Ol & 2.13 \\
\hline 15 & & 1.54 \\
\hline 16 & & \\
\hline & & \\
\hline
\end{tabular}

\begin{tabular}{|c|c|c|}
\hline 17 & 9-Octadecenoic Acid (Z)- & 1.48 \\
\hline 18 & $\begin{array}{l}{[1,2,4] \text { Triazolo[1,5-C]Quinazolinium, 1-Amino- }} \\
\text { 2,3-Dihydro-5-(4-Methylphenyl)-2-T }\end{array}$ & 1.44 \\
\hline 19 & 9,12-Octadecadienoic Acid (Z,Z)- & 1.4 \\
\hline 20 & Hexadecanoic Acid, Methyl Ester & 1.38 \\
\hline 21 & Phytol & 1.38 \\
\hline 22 & $\begin{array}{l}\text { 5-Methoxy-2-(P-Methoxyphenyl)-8H-Thieno(2,3- } \\
\text { B)Indole }\end{array}$ & 1.35 \\
\hline 23 & 22-Tricosenoic Acid & 1.15 \\
\hline 24 & Thunbergol & 1.08 \\
\hline 25 & 2-[P-Methoxyphenyl]-8-Methylcinchoninic Acid & 0.97 \\
\hline 26 & 9,12-Octadecadienoic Acid (Z,Z)-, Methyl Ester & 0.95 \\
\hline 27 & $\begin{array}{l}\text { Hexadecanoic Acid, 2-Hydroxy-1- } \\
\text { (Hydroxymethyl)Ethyl Ester }\end{array}$ & 0.85 \\
\hline 28 & Tetradecanoic Acid & 0.75 \\
\hline 29 & Lup-20(29)-Ene-3,28-Diol, (3.Beta.)- & 0.71 \\
\hline 30 & Ethyl $(9 z, 12 z)-9,12$-Octadecadienoate \# & 0.67 \\
\hline 31 & 9-Octadecenoic Acid, Methyl Ester & 0.63 \\
\hline 32 & Undecane & 0.51 \\
\hline 33 & Benzoic Acid, 4-Fluoro-3-Methoxy- & 0.51 \\
\hline 34 & 2,6,10-Trimethyl,14-Ethylene-14-Pentadecne & 0.49 \\
\hline 35 & $\begin{array}{l}\text { 5-(7a-Isopropenyl-4,5-Dimethyl-Octahydroinden- } \\
\text { 4-Y1)-3-Methyl-Pent-2-En-1-Ol }\end{array}$ & 0.49 \\
\hline 36 & correct & 0.41 \\
\hline 37 & Octadecanoic Acid, Methyl Ester & 0.38 \\
\hline 38 & 3-Isobutoxy-5,5-Dimethyl-2-Cyclohexen-1-One & 0.35 \\
\hline 39 & $\begin{array}{c}\text { 2,6,10,14,18,22-Tetracosahexaene, } 2,6,10,15,19,23 \text { - } \\
\text { Hexamethyl-, (All-E)- }\end{array}$ & 0.35 \\
\hline 40 & $\begin{array}{c}\text { 6,9,10-Trimethoxy-12H-Benz(6,7)Oxepino(2,3,4- } \\
\text { I,J)Isoquinoline }\end{array}$ & 0.35 \\
\hline 41 & $\begin{array}{c}\text { 3,7,11,15-Tetramethyl-2,6,10,14- } \\
\text { Hexadecatetraenyl Acetate }\end{array}$ & 0.34 \\
\hline 42 & Docosanoic Acid, Methyl Ester & 0.33 \\
\hline 43 & Tetracosanoic Acid, Methyl Ester & 0.28 \\
\hline 44 & $\begin{array}{l}\text { Benzoic Acid, 2,4-Dihydroxy-3,6-Dimethyl-, } \\
\text { Methyl Ester }\end{array}$ & 0.27 \\
\hline 45 & 1,1-Dimethyl-4a-Hydroxymethyldecalin-2-Ol & 0.26 \\
\hline 46 & Ethyl (9z,12z)-9,12-Octadecadienoate \# & 0.24 \\
\hline 47 & 2,4,6-Tris(Cyclohexyl)Hept-1-Ene & 0.2 \\
\hline 48 & Eicosanoic Acid, Methyl Ester & 0.17 \\
\hline 49 & 1-Octadecene & 0.15 \\
\hline 50 & Dodecanoic Acid & 0.12 \\
\hline
\end{tabular}

The results of the GC-MS analysis of the ethanol extract of the outer shell of P. suaveolens obtained 50 compounds that were identified. The compound with the highest abundance among the 50 components of the GC-MS analysis was Lupan3-Yl Acetate (12.77\%), followed by 1,3,4,5-TetrahydroxyCyclohexanecarboxylic Acid (8.25\%) and Dl-Threitol compounds with overflow $7.88 \%$. The results of the toxicity and antimicrobial tests showed that the outer shell extract of P. suaveolens was toxic and had strong and very strong inhibitory power for the bacteria S. aureus, E. coli and the 
fungus $C$. albicana. The compound that is thought to have an antibacterial and antifungal role is lupan-3-Yl Acetate. The results of Harizon et al. (2014) have also found that forgotten terpenoid compounds isolated from the mangrove bark of the Sonneratia alba species have strong antibacterial activity. The forgetful compound which is the main active component of the bark extract of Acacia mellifera also shows interesting things as antimicrobial properties(Mutai et al., 2009).

Another compound that is thought to have antimicrobial properties is 1,3,4,5-Tetrahydroxy-Cyclohexanecarboxylic Acid. Research resultSingh et al. (2014)also found the compound found in the ethanol extract of the Naringi crenulata tree (Roxb.) as a bioactive compound that plays an important role as a therapeutic plant. D1-Threitol compound is a compound that has a suspected role of having a high toxicity, this is in accordance with the results of research showing that the DL-threitol compound isolated from the ethyl acetate extract of the root of Croton membranaceus Mull is believed to have strong toxicity.(Bayor, 2007). The results of other studies show that the compound DL-threitol has weak antibacterial properties(Mutai et al., 2009). Another compound that is thought to act as antifungal $\mathrm{C}$. albicans is that found in the outer skin extract of P. suaveolens is alphatocopherol-acetate or vitamin E.

\section{CONCLUSION}

Local knowledge of the Kaili Tribe around Lore Lindu National Park, Indonesia about the use of medicinal plants P. suaveolens, especially the extract of the outer skin, helps the community during the COVID-19 pandemic to cure various diseases. The results showed that the outer shell extract of $\mathrm{P}$. suaveolens contains secondary metabolites, many of which include alkaloids, tannins, saponins and steroids, which causes this extract to have good anti-bacterial and anti-fungal properties. In addition, this extract contains 50 compounds that are thought to have antimicrobial properties including Lupan-3-Y1 Acetate, 1,3,4,5-TetrahydroxyCyclohexanecarboxylic Acid compounds and Dl-Threitol compounds.

\section{ACKNOWLEDGMENT}

We express our gratitude and sincere appreciation to the Kaili Tribe community around Lore Lindu National Park and the Forestry Faculty students who helped and supported us during our research. We also extend our sincere gratitude and appreciation to the Tadulako University International Publication \& Collaborative Center (IPCC) Team, for their assistance in completing this paper.

\section{REFERENCES}

[1] Alfiah, RR, Khotimah, S., \& Turnip, M. (2015). The Effectiveness of Sembung Rambat (Mikania micrantha Kunth) Leaf Methanol Extract Against the Growth of the Candida albicans Fungus. In Journal of Protobiont (Vol. 4, Issue 1). https://jurnal.untan.ac.id/index.php/jprb/article/view/8735

[2] Azizi-Lalabadi, M. (2019). Antimicrobial activity of Titanium dioxide and Zinc oxide nanoparticles supported in 4A zeolite and evaluation of the morphological characteristic. Scientific Reports,
9(1). https://doi.org/10.1038/s41598-019-54025-0

[3] Balali, GI, Yar, DD, Afua Dela, VG, \& Adjei-Kusi, P. (2020). Microbial Contamination, an Increasing Threat to the Consumption of Fresh Fruits and Vegetables in Today's World. International Journal of Microbiology, 2020. https://doi.org/10.1155/2020/3029295

[4] Baud, GS, Sangi, MS, \& Koleangan, HSJ (2014). Analysis of secondary metabolites and toxicity test of the ethanol extract of the stem of the broken bone plant (Euphorbia tirucalli L.) using the Brine Shrimp Lethality Test (BSLT) method. Scientific Journal of Science, 14(2), 106-112.

[5] Bayor, MT (2007). The Anticancer and Other Bioactivity Investigations on the Extract and Some Compounds of Croton Membranaceus [Euphorbiaceae].

[6] Carson, CF, \& Riley, TV (1995). Antimicrobial activity of the major components of the essential oil of Melaleuca alternifolia. Journal of Applied Bacteriology, 78(3), 264-269. https://doi.org/https://doi.org/10.1111/j.1365-2672.1995.tb05025.x

[7] Chokshi, A., Sifri, Z., Cennimo, D., \& Horng, H. (2019). Global Contributors to Antibiotic Resistance. Journal of Global Infectious Diseases, 11(1), 36. https://doi.org/10.4103/JGID.JGID_110_18

[8] Davis, WW, \& Stout, TR (1971). Disc Plate Method of Microbiological Antibiotic Assay: II. Novel Procedure Offering Improved Accuracy 1. Applied Microbiology, 22(4), 659-665. https://doi.org/10.1128/am.22.4.6666-670.1971

[9] De Ornay, AK, Prehananto, H., \& Dewi, ASS (2017). Growth inhibition of Candida albicans and the killing power of Candida albicans from basil leaf extract (Ocimum sanctum L.). Wiyata Journal: Science And Health Research, 4(1), 78-83.

[10] Desai, SD, Desai, DG, \& Kaur, H. (2009). Saponins and their biological activities. Pharma Times, 41(3), 13-16.

[11] Dewi, IP, Fitriani, VY, \& Rijai, L. (2016). Toxicity of Kolowe Leaf (Chydenanthus excelsus) Methanol Extract. In Proceedings of Mulawarman Pharmaceuticals Conferences, 224-227.

[12] Egra, S., Mardhiana, M., Rofin, M., Adiwena, M., Jannah, N., Kuspradini, H., \& Mitsunaga, T. (2019). Antimicrobial Activity of Mangrove Extract (Rhizophora mucronata) in Inhibiting the Growth of Ralstonia Solanacearum Causes Wilt Disease. Agrovigor: Journal of Agroecotechnology, 12(1), 26-31.

[13] Fatmasari, VI, Hapsari, R., Hardini, N., \& Lestari, SR (2020). The Effect Of Vco To The Growth Of Candida Albicans On Denture Basis Of Acrylic Resin. Diponegoro Medical Journal, 9(6), 442447. https://doi.org/E-ISSN: 2540-8844

[14] Fitriani, A. (2014). Alkaloid activity of Ageratum conyzoides L. on the growth of Staphylococcus aureus bacteria in vitro. Proceedings of the XVI Natural Medicines Research Symposium (SPBOA), 67-73.

[15] Gulseven, O., Al Harmoodi, F., Al Falasi, M., \& ALshomali, I. (2020). How will the COVID-19 pandemic affect the UN sustainable development goals? Available at SSRN 3592933.

[16] Harborne, JB (1987). Phytochemical methods: A guide to the modern way of analyzing plants. In Publisher ITB, Bandung. https://asset-pdf.scinapse.io/prod/951357677/951357677.pdf

[17] Herdayanti, H. (2020). Benefits of Herbal Plants as Antifungal against Candida albicans. repository.stickes-bth.ac.id.

[18] Horesh, D., \& Brown, AD (2020). Traumatic stress in the age of COVID-19: A call to close critical gaps and adapt to new realities. Psychological Trauma: Theory, Research, Practice, and Policy, 12(4), 331.

[19] Hu, R., Lin, C., Xu, W., Liu, Y., \& Long, C. (2020). Ethnobotanical study on medicinal plants used by Mulam people in Guangxi, China. Journal of Ethnobiology and Ethnomedicine, 16(1), 1-50.

[20] Huo, C., Dar, AA, Nawaz, A., Hameed, J., Pan, B., \& Wang, C. (2021). Groundwater contamination with the threat of COVID-19: insights into CSR theory of Carroll's pyramid. Journal of King Saud University-Science, 33(2), 101295

[21] Ibraheem, RM, Mhawesh, AA, \& Abood, KW (2018). Estimation of the whole flavonoid, antioxidant, anti bacterial challenge concerning viola odorata (banafsha) methanolic extract. The Iraqi Journal of Agricultural Science, 49(4), 655. 
[22] Iswantini, D., Silitonga, RF, Martatilofa, E., \& Darusman, LK (2011). Zingiber cassumunar, Guazuma ulmifolia, and Murraya paniculata extracts as antiobesity: in vitro inhibitory effect on pancreatic lipase activity. Live Journal of Biosciences, 18(1), 610. https://doi.org/10.4308/hjb.18.1.6

[23] Jahani, S., Saeidi, S., Javadian, F., Akbarizadeh, Z., \& Sobhanizade, A. (2016). Investigating the antibacterial effects of plant extracts on Pseudomonas aeruginosa and Escherichia coli. International Journal of Infection, 3(2).

[24] Kacprzak, K. (2016). Alkaloids and Isoprenoids Modification by Copper(I)-Catalyzed Huisgen 1,3-Dipolar Cycloaddition (Click Chemistry): Toward New Functions and Molecular Architectures. In Chemical Reviews (Vol. 116, Issue 10, pp. 5689-5743). https://doi.org/10.1021/acs.chemrev.5b00302

[25] Kandoli, F. (2016). In vitro test of durian leaf extract (Durio Zybethinus) on the growth of Candida albicans. Pharmacon, 5(1), $46-52$.

https://ejournal.unsrat.ac.id/index.php/pharmacon/article/view/112 23

[26] Meyer, BN, Ferrigni, NR, Putnam, JE, Jacobsen, LB, Nichols, DE, \& McLaughlin, JL (1982). Brine Shrimp: A Convenient General Bioassay for Active Plant Constituents. Researchgate.Net, 45(5), 31-34. https://doi.org/10.1055/s-2007-971236

[27] Muharni, M., Fitrya, F., \& Sofa, F. (2017). Antibacterial Activity Test of Ethanol Extract of Medicinal Plants of the Musi Tribe in Musi Banyuasin Regency, South Sumatra. Indonesian Pharmaceutical Journal, 7(2), 127-135. https://doi.org/DOI :10.22435/jki.v7i2.6070.127-135

[28] Mutai, C., Bii, C., Vagias, C., Abatis, D., \& Roussis, V. (2009). Antimicrobial activity of Acacia mellifera extracts and lupane triterpenes. Journal of Ethnopharmacology, 123(1), 143-148. https://doi.org/https://doi.org/10.1016/j.jep.2009.02.007

[29] Panggabean, L., Nurhamidah, N., \& Handayani, D. (2020). Phytochemical Profile and Cytotoxic Test of Plant Ethanol Extract Zanthoxylum acanthopodium DC (Andaliman) Using BSLT Method. Allotropes, 4(1), 59-68.

[30] Preedy, VR (2010). Bioactive foods in promoting health Probiotics and prebiotics. Academic Press.
[31] Rampe, MJ, \& Tombuku, JL (2016). Phytochemical and toxicity testing of the ethanol extract of the kepok banana flower (Musa paradisiaca LINN.) using the Brine Shrimp Lethality Test (BSLT) method. Journal of Sainsmat, 4(2), 136-147.

[32] Setiari, NMN, Ristiati, NP, \& ... (2019). Antifungal Activity Combination of Betel Leaf Extract (Piper betle) and Citrus Fruit Peel Extract (Citrus reticulata) to Inhibit the Growth of Candida Albicans. Journal of Education.... https://ejournal.undiksha.ac.id/index.php/JJPB/article/view/21931

[33] Singh, N., Meena, MK, \& Patni, V. (2014). Phytochemical profiling and GC-MS analysis of bioactive constituents of callus of Naringi crenulata (Roxb.) Nicolson. Int J Pharm Sci Rev Res, 24(1), 29-34.

[34] Sparg, SG, Light, ME, \& Van Staden, J. (2004). Biological activities and distribution of plant saponins. In Journal of Ethnopharmacology (Vol. 94, Issues 2-3, pp. 219-243). Elsevier. https://doi.org/10.1016/j.jep.2004.05.016

[35] Subhisha, S., \& Subramoniam, A. (2005). Antifungal activities of a steroid from Pallavicinia lyellii, a liverwort. Indian Journal of Pharmacology, 37(5), 304.

[36] Supiandi, MI, Mahanal, S., Zubaidah, S., Julung, H., \& Ege, B. (2019). Ethnobotany of traditional medicinal plants used by Dayak village Community in Sintang, West Kalimantan, Indonesia. Biodiversity, 20(5), https://doi.org/10.13057/biodiv/d200516

[37] Tong, SYC, Davis, JS, Eichenberger, E., Holland, TL, \& Fowler Jr., VG (2015). Staphylococcus aureus infections: epidemiology, pathophysiology, clinical manifestations, and management. Clinical Microbiology Reviews, 28(3), 603-661. https://doi.org/https://doi.org/10.1128/CMR.00134-14

[38] Wolde, T., Kuma, H., Trueha, K., \& Yabeker, A. (2018). Antibacterial activity of garlic extract against human pathogenic bacteria. J Pharmacovigil, 6(1), 1-5.

[39] Yeshiwas, Y., Tadele, E., \& Tiruneh, W. (2019). The dynamics of medicinal plants utilization practice nexus its health and economic role in Ethiopia: A review paper. International Journal of Biodiversity and Conservation, 11(1), 31-47. 